DOI: https://doi.org/10.24297/jssr.v14i0.8157

\title{
Is The Criminal Justice System Blind to Race and Ethnicity?: The Case of Fatal Work Accidents in The Construction Industry
}

Eitan Nictora, Efrat Shoham and Sima Ben-Zur

\author{
Dr. Eitan Nicotra \& Prof. Efrat Shoham - Criminology Department, Ashkelon Academic College, Israel \\ Sima Ben Zur - Justice Department, Ashkelon, Israel. \\ enicotra@gmail.com, Shoham@netzer.org.il
}

\begin{abstract}
Despite growing media and public interest in recent years in the issue of fatal work accidents in the construction industry, there in fact has been an upswing in the number of fatalities. The construction industry is a dangerous industry for workers, and about half of the fatal work accidents in Israel take place there. This study was designed to examine how the law enforcement system handles cases of fatal work accidents, where most of the workers are foreign workers. The article examines whether there is a difference in the criminal procedures between work accidents and road accidents, which are not identified with a particular demographic sector. The study findings showed that there is a significant link between the type of fatal accident and the identity of the victim, and the decisions made during the criminal proceedings for a fatal work accident as compared to a fatal road accident. The findings partially correspond with the assumptions of the Marxist structural school of victimology, which sees a relationship between the victim's social status and the way the criminal justice system handles the case.
\end{abstract}

Keywords: Marxist victimology, victims, fatal work accidents, foreign workers, prosecution authorities, courts.

\section{Introduction}

In recent years, there has been growing media and public involvement in the phenomenon of fatal work accidents in the construction industry in Israel. However, it appears that the number of fatal work accidents in this sector continues to rise. From the beginning of 2016 until the end of May 2018, 100 workers were killed in construction-related work accidents. From the beginning of 2018 to the end of May 2018, 17 construction workers were killed in work accidents, an increase of 30\% compared to the same period in 2017 (Danieli, 2018, May 30). The construction industry is perceived as the industry where most serious accidents occur. On average, about half of the fatal work accidents in the Israeli economy take place in the construction industry. In 2015 and 2016, the number of construction work fatalities rose to approximately 63\% of all fatal work accidents. Most of the workers in the construction industry are foreign workers, compared with other manufacturing industries, where most of the employees are Israelis. In addition, the chance of a foreign worker losing his life in construction is more than double that of an Israeli worker (Cohen, Ra'anan, \& Gittelson, 2016).

A work accident is defined as fatal when it occurred during work and caused the worker's death (Zeira, 2016, February 8). Almost every week there is a news item about a construction worker or crane operator who was seriously injured or even killed. A document written in December 2015, for a discussion in the Knesset's (the Parliament of Israel) Labor, Welfare and Health Committee, noted that the International Labor Organization classifies the construction industry as one of the most dangerous sectors for employees. In Israel, too, work in the construction industry is identified as a high-risk job. The Israeli Occupational Safety and Health Administration (hereinafter "the Safety Administration") notes that the construction site is a complex and constantly changing work environment, and the use of powerful machinery and tools creates risks. Additional features that increase risk is the presence of employees who do not know the particular risks of the site, the lack of professionalism and skills of some of the employees, and strenuous work performed in difficult and 
changing weather conditions. The report of the committee appointed to examine the areas of occupational safety and health ("Adam Committee", 2014) reveals "one of the main problems in the field is the absence of a single, comprehensive national database; information sharing between the bodies is very limited and almost nonexistent, the official reasons for which are legal constraints and technical limitations. However, the root cause is the fact that these agencies do not share the same goal. Each agency has different and sometimes conflicting interests. The absence of a clear general picture of the state of safety and health in the Israeli economy imposes a serious barrier to the state's ability to identify the processes and to manage the field in an effective and optimal manner "(Committee Report, p. 94).

One of the central theories in radical victimology is the Marxist approach to victimology. Like various theories in the framework of critical criminology, Marxist victimology posits that society is composed of many different interest groups with built-in conflicts between them. According to this view, social problems such as crime, poverty, and victimization can only be resolved by a fundamental change in the social order (Matthews, 2014). The main instruments of social supervision and exclusion (Foucault, 2015) are the criminal law and the law enforcement system. This approach focuses the discussion on victims in contexts of racial discrimination and exploitation based on gender and social status. According to Landau (2003), victimhood reflects an inability to oppose the offender because of physical, economic, cultural, and social deficiencies and barriers. Given this, foreign workers can be seen as a type of victim of social, economic, and cultural disadvantages. These workers, who usually do not know the language or are unaware of their rights, frequently move from the periphery to the city, and are without the means and experience to fight back and to maintain their civil rights (Shoham, 2009).

Fatal accidents characterize two main areas: road accidents and work accidents, mainly in the construction industry. The aim of this study is to examine how the law enforcement system addresses these two types of fatal accidents. This examination will focus on the years 2011-2017 and will investigate how the Southern District Attorney's Office handled fatal work accidents compared to how a sampling of fatal road accidents was treated in the same district.

Fatal road accidents were chosen as the basis for comparison because they are similar to fatal work accidents in many ways: they have a fatal result, occur in a dangerous environment, are regulated by special legislation, and usually result from violating a law or regulation designed to reduce the phenomenon and increase enforcement. However, as opposed to fatal construction work accidents, road accidents are not identified with any particular sector: they threaten almost everyone who drives or walks on the roads and thus receive increased media attention and law enforcement.

\section{What is the "victimology" of work accident victims?}

Victimology is the field of scientific research of various aspects related to the victim of crime, including victimoffender relations, victim-crime relations, and the victim's relationship with the legal and welfare systems. Victimological examination is highly complex and studies the image of crime victims as portrayed in the media, in public discourse, in criminal proceedings, and in political responses to crime. It also examines the existing and desirable relationship between victim and offender, the consequences of the crime, its impact on the victim, and the physical and socio-economic costs that result therefrom (Kirshenbaum, 2009).

Radical victimology is related to the work of Benjamin Mendelson (1963; Simpson, 1989), who is considered the founder of the field of victimology. It is based on radical sociological and criminological theories and shares certain premises with them: first, society is composed of a number of groups and there is conflict between them. Second, the purpose of the law is to support or preserve the existing social power structures, and third, that solving social problems such as poverty and crime can only be done by a fundamental change in the social order. Accordingly, the law enforcement system will use repressive methods against various groups in society as a whole and not only against criminals (Kirchhoff, 1990). 
Arifi (2016) describes the Marxist school of radical victimology that emphasizes division into classes and social inequality as an important factor in crime and victimhood. Marxist victimology focuses on the victims of any oppression, including victims of rights violations, abuse of power, and discrimination on grounds of race or social status (Elias, 1986; Taylor, Walton, Young, 1975). The universal causes of victimhood, according to Marxist victimology, are the state, the social order, and the privileged, but Falandysz (1982) believes that the real criminals, who are powerful and hold higher social status, are rarely prosecuted.

Although 2018 marked the 200th anniversary of the birth of Karl Marx, the preoccupation with the status of foreign workers to this day reinforces the claim of Marx and Engels (Marx and Engels, 1975; Zisser, 1999): that the historical processes of production relations and inequality at the capitalist stage brought the state to become an interested party in the struggle between the classes, which tends to consistently support the economic and political interests of the wealthy. However, Larnau (2016) explains that instrumental Marxism, which views the law and the governing authorities as a tool serving the powerful to assert economic and social control, is to some extent too simplistic, and the structural Marxism that developed later is based on the understanding that economic and political forces operate in partial autonomy which is affected by a wide range of conflicting interests. Thus, the interests of the wealthy are only part of the range of interests affecting legislation and law enforcement. According to this approach, while the law is not in the hands of the wealthy, the capitalist economy is also perceived as a principle that organizes and shapes the development of law and justice. The preservation of social stability, a significant part of which is based on economic stability and preserving the capital market, indirectly leads the law enforcement system to preserve the interests of the wealthy.

While liberal democratic societies share a common social and legal rhetoric that emphasizes the value of equality, the conflict theories which include the Marxist approach, consider the legal use of the terms 'equality, justice, and fairness' as lip service used to conceal a reality of inequality and exploitation under cover of the law. These critical theories seek to expose the misrepresentation by legal rhetoric and show how laws and social institutions actually serve the interests of the powerful (Hacker, 2008; Haney, 1991). According to these theories (Shoham \& Doron, 2016), the identity of the "other" social groups varies according to the lines of conflict highlighted in each of the theoretical streams.

Inequality in the law enforcement system's conduct toward majority and minority groups and toward different ethnic and racial groups has led Rattner and Fishman (2004) to examine, for example, the attitude of the Israeli legal system towards Jews and Arabs suspected of committing crimes. In a longitudinal study between 1980 and 1992 with a follow-up study between 1985 and 2000, they corroborate the assumption that discrimination against Arabs also exists in the courts. The researchers believe that the legal and court system's attitude towards Israeli Arabs may be part of the broader social attitude in the country, which views Israeli Arabs as a foreign element in Israeli society. Elbashan (2005) writes in his book, Strangers in the Realm of the Law, that sometimes a certain social sector, usually a minority or a weak group, experience a sense of inferiority in a court of law, which it sees as a foreign, discriminatory, and even hostile arm of government. The identity and alienation of the poor, minorities, foreign workers, and new immigrants stem from their being different and weak as they stand before judges representing the country's powerful elites.

This description may also fit workers in the construction industry in Israel, most of whom are foreign workers. They have no lobby or social power and are a minority group. Facing them are contractors who are usually wealthy and can afford to use expensive lawyers. Foreign workers, including Palestinian workers, are not aware of their social rights: employment and wage terms, health and safety requirements, and eligibility for health insurance and national insurance. This creates an incentive to exploit them and employ them in unlawful conditions, and this encourages replacing Israeli workers with foreign workers without rights (Nathan, 2011; Shoham, 2009). Even when a fatal work accident occurs and a foreign worker is killed, his friends usually do not know the language and even if they witness their friend's death, it is difficult for them to give a clear version of what happened. Sometimes the accident happens without witnesses since the construction site is a closed area with few people present. The workers are also afraid to talk because they do not want to expose 
negligent behavior, whether by the contractor or by the victim. They work on "outputs" and at times disregard and deviate from work procedures to reach the "output". They desperately need this income, so most of them agree to work for a meager wage despite the hard physical work.

In August 2008, following a petition to the High Court of Justice filed by human rights organizations, the state stopped registering the employer's name in the foreign worker's passport and allowed them to change employers and move to other districts, once a quarter. However, migration between industries is still not permitted (for example from agriculture to construction, etc. (Shoham, 2011)). Human rights organizations throughout the Western world and in Israel, too, are engaged in a critical analysis of the treatment of foreign workers. These organizations assist labor migrants in various ways, such as increasing awareness of their rights, legal aid, legislative changes, and media and public struggles. In their view, foreign workers are victims of globalization and capitalism. They believe that these two create a phenomenon of modern slavery - the representatives of the affluent world exploit the representatives of the hungry world and use them as a cheap labor force to work at what is defined in the discourse of workers' rights as " the three D's - Dangerous, Difficult, Dirty" (Feldman, 2008).

\section{Fatal work accidents in the construction industry}

The National Insurance Institute and the Ministry of Economy reports show that of all manufacturing industries, the construction industry is the most dangerous to the worker's safety in Israel. Of 112 workers killed in 2015- 2016 in all manufacturing industries, 70 (62.5\%) were killed on construction sites. In 2015, the probability of a construction worker being killed at work was higher than that of his counterpart in any other industry (Cohen, Ra'anan, \& Gittelson, 2016). Between 2012 and 2016, there was a 16\% increase in the number of workers killed in the construction industry, compared to a corresponding decline in the manufacturing, services, and trade industries for the same period.

According to the data of the Safety Administration, a subdivision in the Ministry of Labor, Social Affairs and Social Services, (Cohen, Ra'anan, \& Gittelson, 2016, Ra'anan, Cohen, Gittelson, \& Barna, 2017) and data published by the Knesset Information and Research Center (Zeira, 2015), between 2011-2016, some 220 workers were killed in construction accidents, approximately $54 \%$ of the fatal work accidents in all industries. About 52\% of those killed in the construction industry in 2010-2016 were foreign workers and Palestinian workers (119 killed) and 48\% Israeli residents (110 killed). The Safety Administration data note no distinction between Palestinian workers and foreign workers. In 2016, the rate of non-Israelis killed was greater than that of Israelis (as high as 68\% in 2012).

Chart 1: Comparison of the Number of Fatalities by Residence Status in the Construction in Israel, 2010 2016 * 


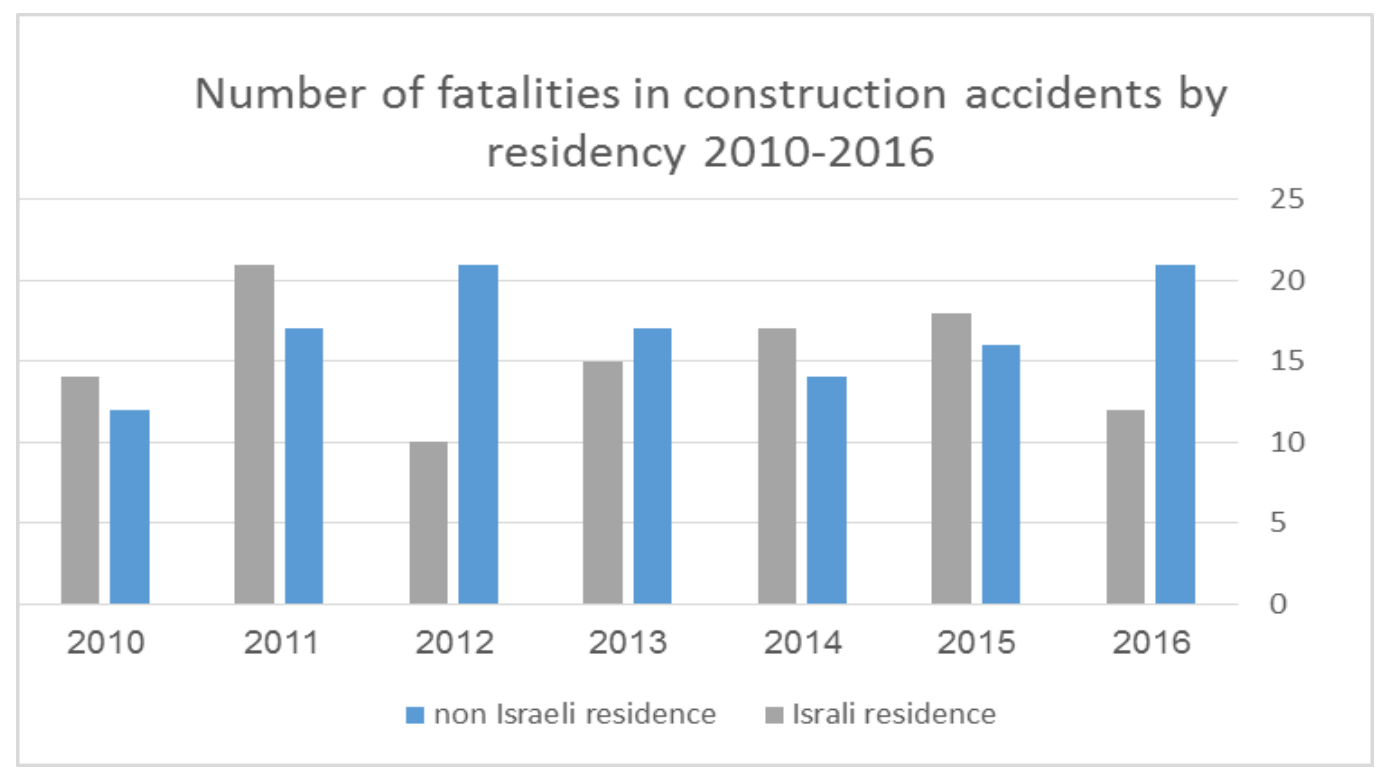

Chart 1 is based on charts and data published by the Safety Administration (Gittelson, Cohen \& Ra'anan, 2015), (Cohen, Ra'anan \& Gittelson, 2016), (Ra'anan, Cohen, Gittelson \& Barna, 2017).

The division between Israeli and non-Israeli residents does not reflect the full problem in the construction industry, since many of the fatalities are Israeli Arab residents, who suffer from discrimination as well. However, no data has been published on this issue (Labor, Welfare, and Health Committee of the Knesset, 5 February 2018).

In comparison to other countries, Israel ranks third in the number of workplace fatalities in the construction industry, relative to the number of employees (Cohen, Ra'anan, \& Gittelson, 2016).

According to the Coalition against Building Accidents, the weakest and most vulnerable groups among construction workers are foreign workers, Palestinian workers, and Israeli Arabs. These vulnerable groups all share the desire to earn a living at all costs. As stated, the probability of a foreign worker losing his life in the construction industry is twice as high as of an Israeli worker (Zeira, 2015).

\section{Law enforcement in cases of fatal work accidents in the construction industry}

Unlike a work accident without casualties, when a person is reported killed or seriously injured in a work accident, the responsibility for conducting a criminal investigation rests with the Israeli Police. In such cases, the police arrive at the scene to investigate the incident and classify it as a work accident, criminal event, suicide, or other event. When the police classify it as a work accident, they report it to the Safety Administration and request an expert opinion from safety inspectors regarding the causes of the injury. Safety experts are called in because this is a complex field that requires legal and professional expertise. After collecting the available evidence, the case is handed over to the State Attorney's Office to decide whether to indict or close the case. In such offenses, the police have no standing in the decision about handling the case (Cohen, Ra'anan, \& Gittelson, 2016; Ra'anan, Cohen, Gittelson, \& Barna, 2017).

According to the Safety Administration, its limited staff makes it difficult to execute its job. There has been no increase in positions despite the increase in the number of construction sites and tasks it is assigned. It was further noted that even with the current staff, the Safety Administration has difficulty with recruiting inspectors due to the low wages, relative to the complex and difficult job, and it is hard to retain existing employees (Bassol, 2016). According to the State Comptroller's report of 2016, between 2009 and 2014, the Safety Administration inspectors visited less than $2 \%$ of the construction sites where accidents occurred. In some cases, the investigation is incomplete and the case returns to the police, which sends it back to the Safety 
Administration. This may happen because the workers-witnesses are already back in their homeland and are difficult to trace, and sometimes the crime scene cannot be reconstructed, and it usually has changed since the accident.

Given these facts, the present article investigates whether there is a correlation between the nature of the fatal accident, the identity of the victim, and the nature of the decision made in cases of fatal work accidents in the construction industry compared to fatal road accidents. Additionally, whether the decisions made by law enforcement agencies and courts vary according to the type of accident (fatal construction work accident compared to a fatal road accident), i.e., whether there are differences in the grounds for closing cases, in the rates of indictments filed, in the rate of plea bargains, in the severity of punishment, and whether there is a statistical relationship between these decisions and the identity of the accident victim.As noted, fatal road accidents were chosen as a basis for comparison because they are similar in some respects to fatal construction work accidents, but unlike them, they are not identified with any particular sector: they threaten all individuals in society and receive increased media and enforcement attention.

The study assumes that in the case of fatal work accidents in the construction industry, fewer indictments will be filed compared to fatal road accidents, and that if an indictment is filed, punishment for causing fatal road accidents will be more severe than for fatal construction work accidents.

\section{Method}

To examine these assumptions, all files of the Southern District Attorney's Office opened for fatal work accidents in the construction industry between 2011 and 2017 were selected, a total of $\mathbf{3 3}$ files. In addition, 33 cases of fatal road accidents were sampled out of the total number of fatal road accident files opened in the Southern District during those years. Of the total number of fatal accidents, $55.6 \%$ are Israeli workers and $44.4 \%$ are foreign workers (Palestinians are included in foreign workers).

There is great difficulty in obtaining nation-wide data from the State Attorney's Office and the police due to the inability of the computer system of the State Attorney's Office to distinguish between the different reasons for causing death, and a discrepancy between the police and prosecution case numbers (Zeira, December 27, 2017), as well as the lack of a centralized data base. Therefore, this study was based on data collected manually from the Southern District Attorney's office only from 2011 to 2017, where the number of cases was relatively small.

The analysis of the cases was based on a content-analysis questionnaire of judicial decisions, which was composed by Shoham and Abulafia (2010) and adapted to fatal construction work accidents and road accidents. From the sampled cases, the following variables were extracted: type of case (construction work or road accident); identity of the accident victim (Israeli or foreign worker, where Palestinians were considered foreign workers)), was the case closed without filing an indictment, and if so, on what grounds; was an indictment filed; was a plea bargain reached; and what type of punishment was meted out in case of a conviction; and how much time passed from the accident until the attorney's office received the case (in days). After data was collected, we compared the data on fatal work accidents in the construction industry (hereinafter: 'construction accidents') with data on fatal road accidents and we analyzed the correlations between type of accident, identity of victim, and the state attorney/court's ruling by using social science correlation tests.

\section{Findings}

The characteristics of handling all fatal accident cases (road accidents and construction accidents) in the sample -

In slightly more than half of the cases opened in the Southern District between 2011 and 2017 for fatal accidents (54\%), no indictments were filed. 
In cases where no indictment was filed, two main reasons were found for closing the case: $\mathbf{4 8 . 5 \%}$ of the cases were closed on grounds of insufficient evidence, $\mathbf{4 8 . 5 \%}$ of the cases were closed on grounds of absence of guilt or no criminal offense, and 3\% were closed due to lack of interest to the public (Chart 2).

Chart 2: Distribution of grounds for closing cases in all cases in the sample

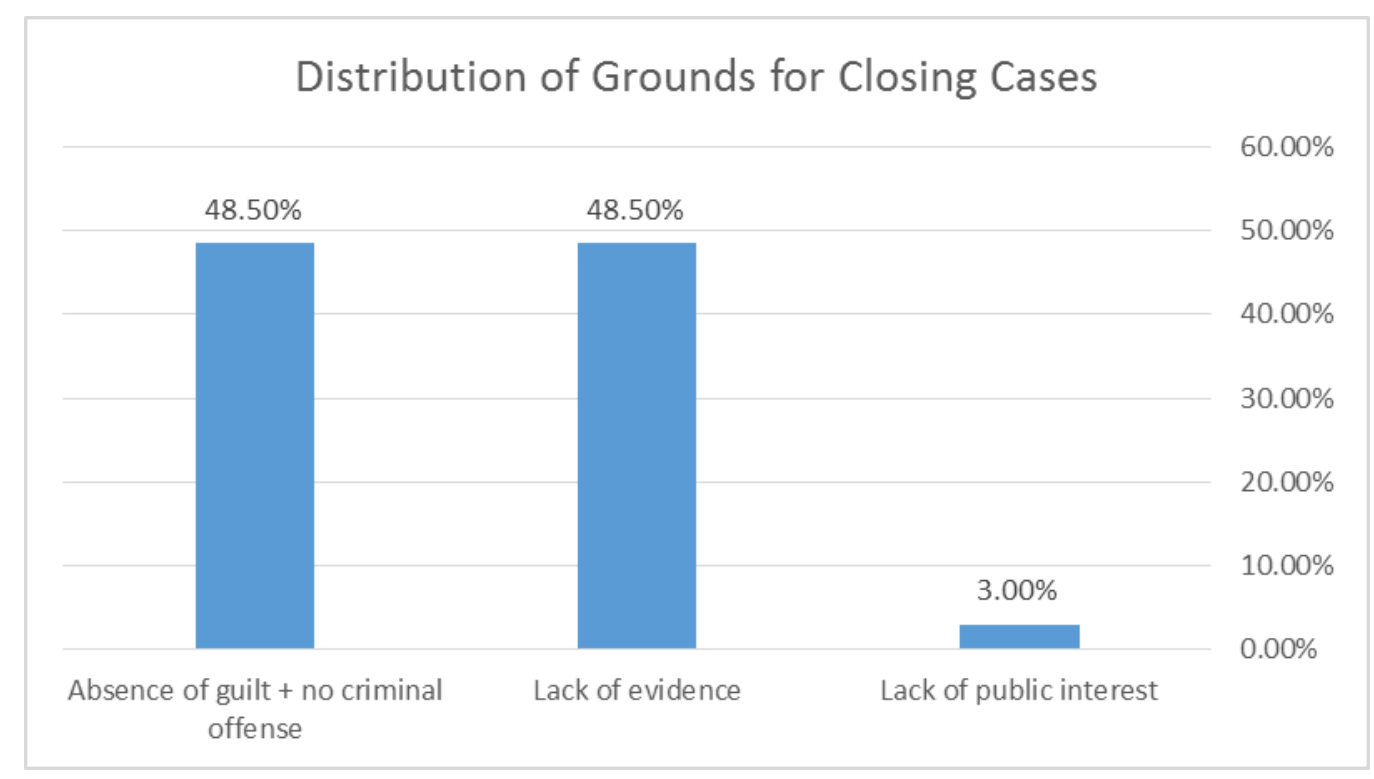

The grounds "No criminal offense" began to appear only in the fatal construction accident cases that were closed in 2017. It should be noted that this cause does not constitute grounds for official closure according to the State Attorney's directives (Directive 1.3, 2018, January 14). It is mentioned in the police procedure relating to "reasons and considerations for closing criminal cases" (Procedure No. 300.01.152, 2014, February 1) and is designated for cases where the act under investigation does not constitute a criminal offense. In such a case, the complaint is set aside as general material (with no suspect). Since the grounds for closing due to absence of guilt and no criminal offense are almost identical in essence, we treated them together. In some $90 \%$ of the cases where an indictment was filed (28 cases), a plea bargain was made, and only about $10 \%$ (three cases) did not make a plea bargain.

In order to examine the distribution of punishment in the cases sampled, where an indictment was filed and a ruling was given, we grouped the punishments into three categories: monetary compensation only, 
community service work (with or without monetary compensation), and imprisonment (with or without monetary compensation). In approximately $\mathbf{4 3 \%}$ of the cases, prison sentences were imposed; in some $\mathbf{3 2} \%$ of the cases, community service was imposed, and in $\mathbf{2 5 \%}$ of the cases only monetary compensation was ruled (Figure B). If we relate only to monetary compensation (as a single punishment or as supplementary to other punishment), in $\mathbf{8 6 \%}$ of the cases (24 cases) monetary compensation was decreed, and in approximately $14 \%$ (4 cases) the offenders were sentenced to imprisonment or community service without compensation.

Chart 3: Distribution of punishments in cases where indictments were filed

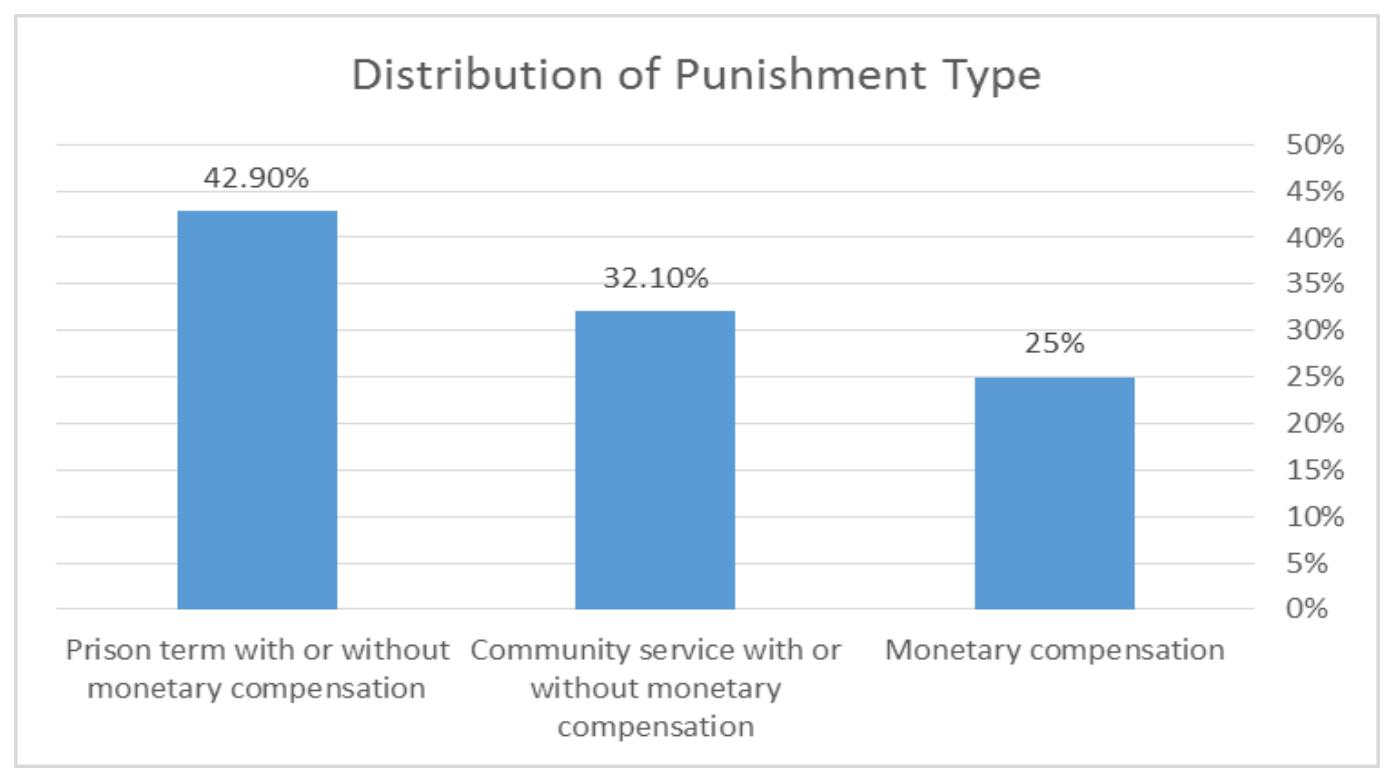

\section{Correlations between type of accident, identity of the victim, and judicial rulings}

In this section, we seek to examine whether there is a relationship between the type of accident (road or construction accident) and the identity of the victim (Israeli or foreign worker) and the various decisions made during the criminal proceedings, such as:

A. The relationship between the type of fatal accident and the identity of the victim;

B. The relationship between the type of fatal accident and the filing of an indictment;

C. The relationship between the identity of the victim in fatal construction accidents and the decision to file an indictment;

D. The relationship between the type of fatal accident and the grounds for closing the case; 
E. The relationship between the type of fatal accident and a plea-bargain;

F. The relationship between the type of fatal accident and the identity of the victim and the punishment imposed.

\section{A. The correlation between the type of fatal accident and the identity of the victim}

In fatal construction accidents, $\mathbf{6 0 . 6 \%}$ of victims were foreign workers, and $\mathbf{3 9 . 4 \%}$ were Israeli workers. Of foreign workers in the sample killed in accidents, $\mathbf{7 1 . 4 \%}$ were killed in construction accidents, and $\mathbf{2 8 . 6 \%}$ of them were killed in road accidents. Of the Israeli workers in the sample, $\mathbf{3 7 . 1 \%}$ were killed in construction accidents and $\mathbf{6 2 . 9 \%}$ were killed in road accidents.

Analysis of the data shows that there is a significant correlation between the type of accident (a road accident or construction accident) and the identity of the victim (Israeli or foreign worker) $(\chi 2(1)=7.33, p<0.01)$.

\section{B. The relationship between the type of fatal accident and filing an indictment}

A significant correlation was found between the type of fatal accident and the decision of whether or not to file an indictment $(x 2(1)=21.64, p<0.01)$.

In approximately $\mathbf{8 2} \%$ of all fatal construction accidents in the sample, no indictment was filed, compared to $\mathbf{2 3} \%$ of the fatal road accidents where no indictment was filed. Of the fatal construction accidents, an indictment was filed in $\mathbf{1 8 \%}$ of the cases, compared to $\mathbf{7 7 \%}$ of fatal road accidents.

It should be noted that this figure relates to how the law enforcement agencies handle the various types of fatal accidents in general, and one should not draw conclusions relating to the identity of the victim (Israeli or foreign worker).

It was also found that there is a significant correlation $(t(39.74)=5.63, p<0.001)$ in the time that passed until the case reached the District Attorney's office; i.e., the period of time that elapsed from the date of the fatal accident until the case was received at the District Attorney's office. While in the case of fatal road accidents, the average lapse of time was 154 days (about five months) ( $\mathrm{sd}=138$, median $=111$, minimum $=8$, maximum = 704), the time that elapsed in fatal construction accident, was $\mathbf{5 5 8}$ days on average (about one and a half years) $(s d=338$, median $=435$, minimum $=134=1593)$.

\section{The relationship between the victim's identity in fatal construction accidents and the decision to file an indictment}

In $\mathbf{9 0 \%}$ of cases where a foreign worker was killed in a fatal construction accident, no indictment was filed, as compared with $\mathbf{6 9 \%}$ of the cases in which an Israeli was killed in a construction accident. Nonetheless, no statistically significant correlation was found between the identity of the victim and the type of accident and the decision of whether or not to file an indictment.

\section{The relationship between the type of accident and the grounds for closing the case}

The large number of cases in which indictments were not filed despite the fact that there was a fatality, led us to examine the grounds for closing the cases and the possibility of correlation between the grounds for closure and the type of fatal accident.

Chart 4: Distribution of grounds for closure by type of case 


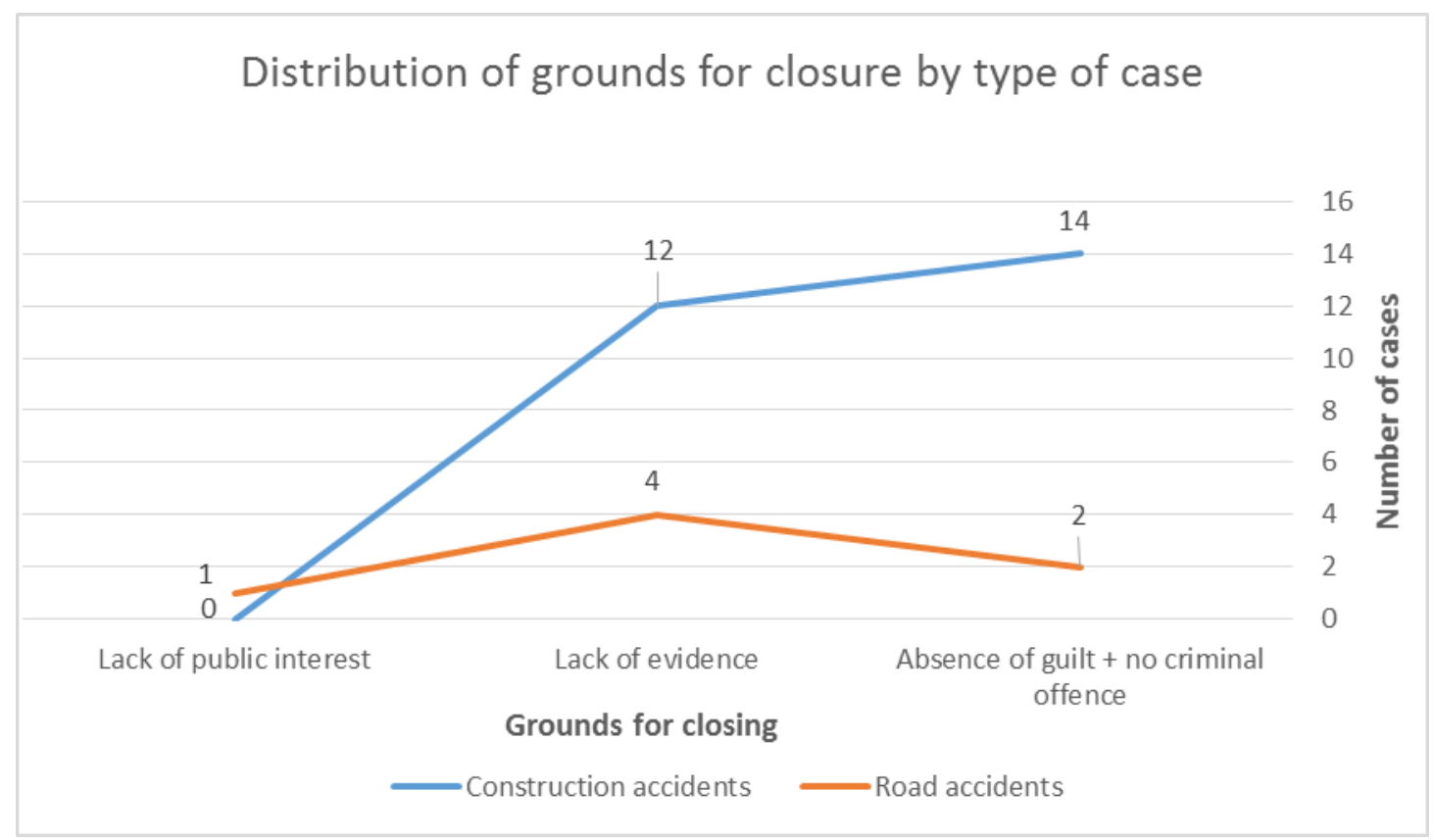

Of all cases closed on grounds of no fault (no criminal offense), $\mathbf{8 7 . 5 \%}$ were fatal construction accidents and $\mathbf{1 2 . 5 \%}$ were fatal road accidents. It should be noted that the grounds for closure "no criminal offense" appears in 10 fatal construction accident cases in 2017 and does not appear at all in fatal road accident cases.

Of all cases closed due to lack of evidence, $\mathbf{7 5 \%}$ were in fatal construction accidents and $\mathbf{2 5 \%}$ in fatal road accidents.

\section{E. The relationship between the type of fatal accident and plea bargaining}

The correlation between the type of accident and reaching a plea bargain was examined only for the 28 cases where an indictment was filed. In $\mathbf{1 0 0 \%}$ (5 cases) of the cases of fatal construction accidents where an indictment was filed, a plea bargain was reached. In $\mathbf{8 7 \%}(20$ cases) of the cases of fatal road accidents in the sample in which an indictment was filed, a plea bargain was reached. The findings indicate an insignificant difference (Fisher's exact test $p=0.541$ ). However, it should be noted that the small number of fatal accident cases in which indictments were filed in the Southern District makes it very difficult to find significant differences.

\section{F. The relationship between the type of fatal accident and identity of the victim and the level of punishment}

An analysis of the cases shows that there are no significant differences (Fisher's exact test $p=0.127$ ) between the type of punishment and the type of accident (Figure 5).

Chart 5: Relationship between type of accident and type of punishment 


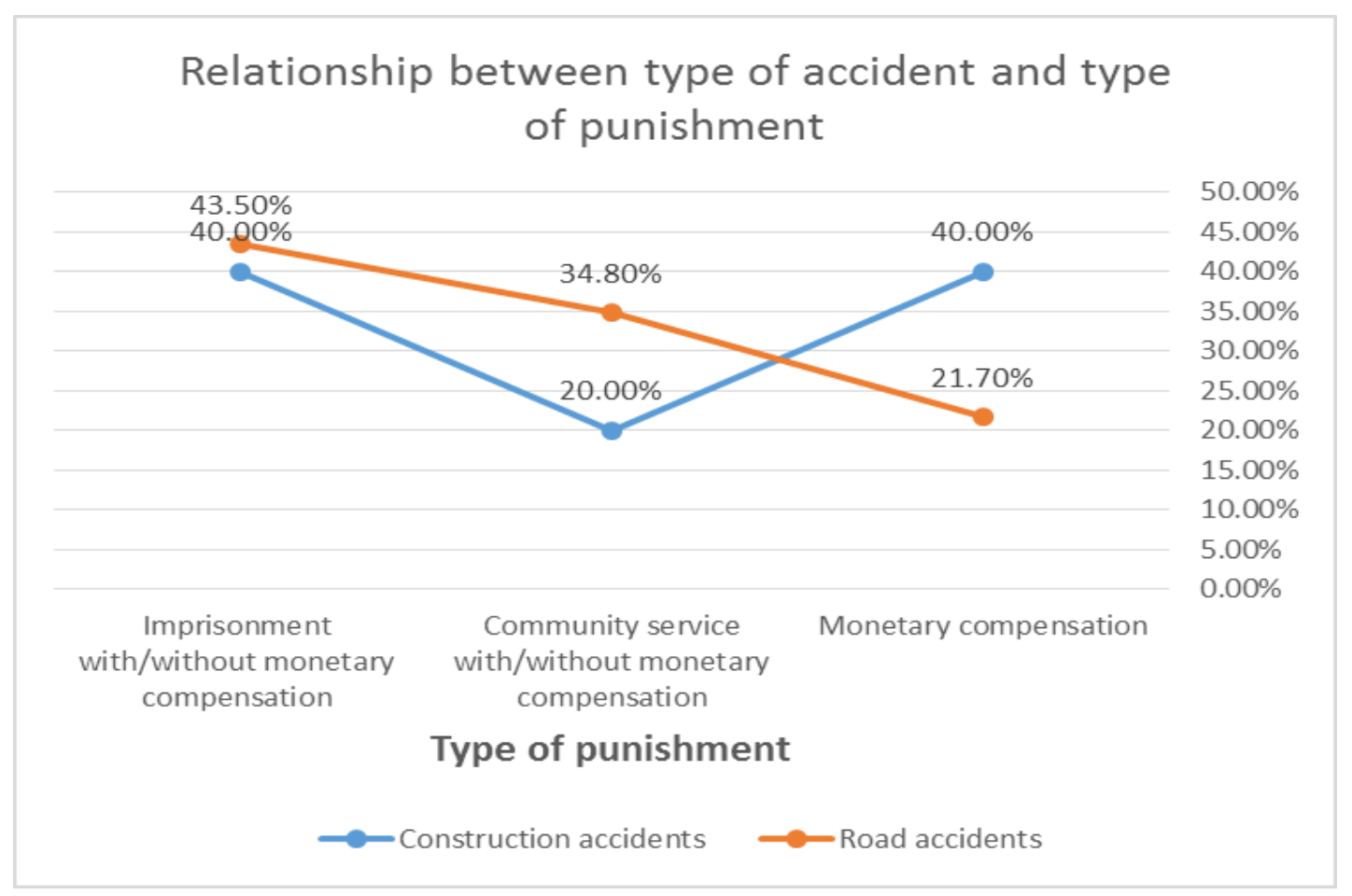

Prison sentences were imposed in similar percentages in both types of fatal accident, about $40 \%$. However, to some extent, more fines were imposed than community service punishments in fatal construction accidents than in fatal road accidents.

On the other hand, when we examine the relationship between the identity of the victim and the type of punishment, a significant difference was found (Fisher's exact test $p=0.015$ ) (Figure 6).

Chart 6: The relationship between the identity of the victim and the type of punishment

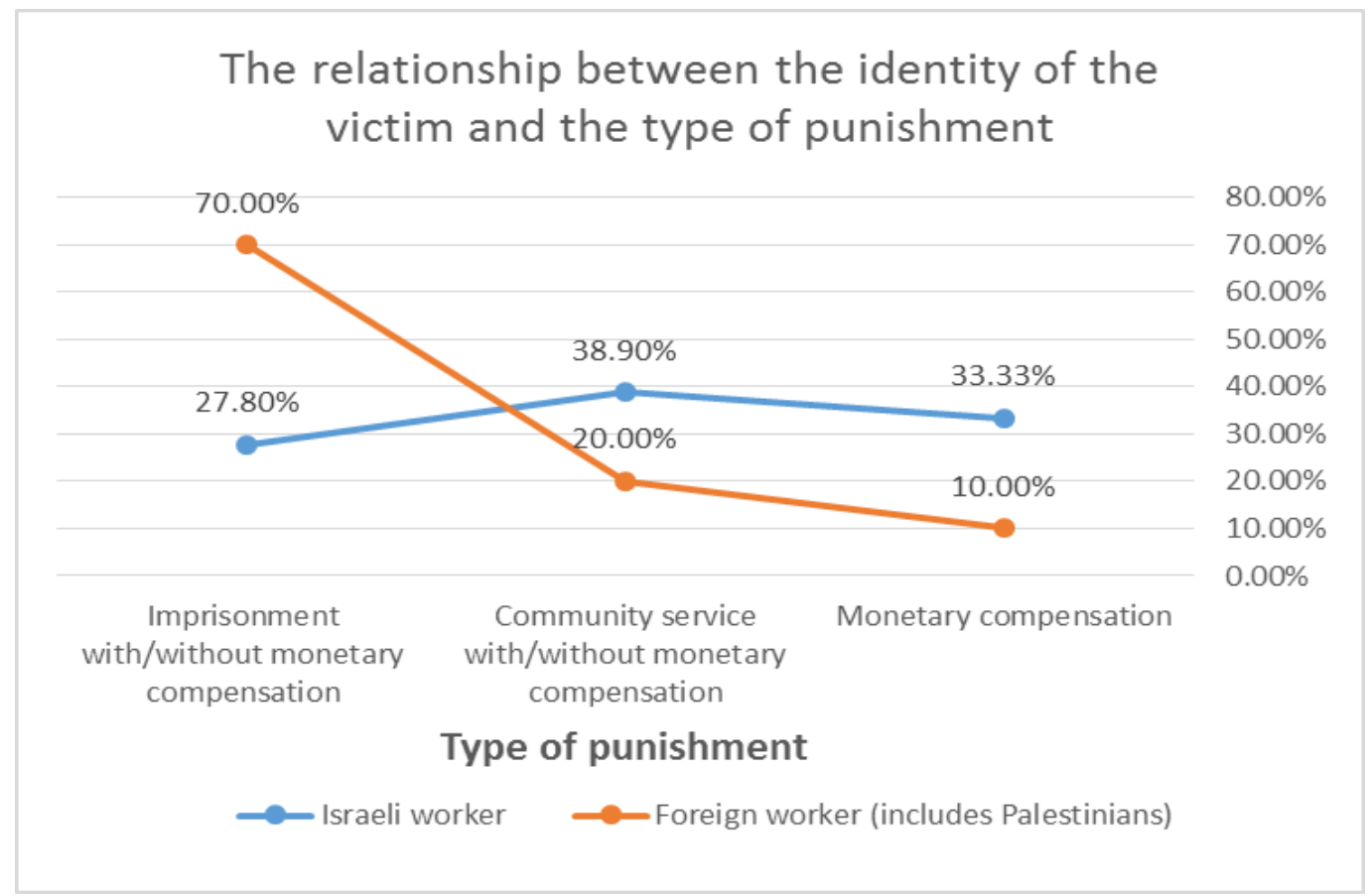


The data shows that while for the Israeli victim, the distribution of the various punishments is similar (about one-third for each type of punishment), for victims who are foreign workers (including Palestinians) the punishment level is actually much stricter: $\mathbf{7 0} \%$ of the sentences include a component of imprisonment.

\section{Discussion}

As early as the middle of 2016, the State Attorney stated that the investigation of work accidents in the construction industry in Israel is beset with an "inherent difficulty" and failures, stemming mainly from a faulty working interface between the Ministry of Economy inspectors and the Israel Police. Work accident cases do not receive optimal treatment, and there is systemic difficulty in this field (Yaron, 2017).

The purpose of this study was to examine whether the assumptions of the Marxist school of victimology are reflected in the way the law enforcement system handles cases of fatal construction accidents where most of the workers come from populations defined as disadvantaged and weakened.

An analysis of the findings indicates that cases of fatal construction accidents reached the State Prosecutor's Office too infrequently and too late. The files arrived a long time (558 days on average, or about a year and a half) after the accident accured. The agencies reports show that in most cases, there are missing details that make it difficult to reconstruct the crime scene and complete the investigation, since it is an active and ongoing construction site and the original crime scene has changed completely by the time the investigator arrived (Ra'anan, Cohen, Gittelson, \& Barna, 2017). Furthermore, in some cases it is impossible to locate eyewitnesses, and even when they are located and do testify, they do not always remember or want to experience the difficult situation again or confront their employer. Even after testifying, as foreign workers, they may no longer be in Israel during the trial (Zeira, 2015). In fatal road accidents, the situation is completely different. The files arrived at the State Attorney's Office after a relatively short period of time (154 days on average, or five months). In most cases, there is no need for further investigation because these accidents were investigated by a trained police traffic examiner, who closed the scene, took photographs, located and questioned the suspects and witnesses, all in real time, and later on documented it in the file.

The study also found significant differences regarding the decision to file indictments in the various types of accidents. In those cases where no indictments were filed, despite the fact that a construction worker was killed, the social response to this case actually ends. Since these are mainly victims from a weakened social group, one can expect that no civil suit will be filed and that family members who are mostly not Israeli citizens and who do not reside in Israel will not attempt to take additional action.

Only $18 \%$ of the fatal construction accident cases were indicted compared to the $\mathbf{7 7 \%}$ of fatal road accident cases. Of the files that were closed due to lack of evidence, $\mathbf{7 5 \%}$ were construction accident cases, compared with $\mathbf{2 5 \%}$ of road accident cases closed for the same reason. It is possible that not only the victim's identity, but also the difficulty in obtaining evidence and witnesses in these cases, cause these files to be closed on grounds of absence of guilt and no criminal offense. The reports indicates that in many cases, the evidence is so scant or weak that suspects cannot even be identified (Zeira, 2015). Accordingly, the findings of the study show that of all cases closed on the grounds of no guilt and no criminal offense, $\mathbf{8 1 \%}$ were in fatal construction accident cases and only $19 \%$ were in road accident cases. This seems to be the reason why the Southern District Attorney's Office has begun to use "no criminal offense" as grounds for closing, although it is not a reason for closing a criminal case under the Attorney General's instructions. Apparently, it is used because of the inability to obtain even basic evidence from the crime scene.

A significant correlation was also found between the type of accident and the identity of the victim. Of the 33 construction accident cases, in 20 cases (60.60\%), foreign workers were killed and in $\mathbf{1 3}$ cases (39.40\%), Israeli workers were killed. Most of the victims of fatal construction accidents are foreign workers, who are part of a weakened social group (Shoham, 2009). The use of the word "weakened" rather than "weak" is chosen to suggest that the situation of this population does not stem from a defect in its members' behavior, but rather from a defect in society's attitude toward them, such as ongoing discrimination or the existence of a glass 
ceiling. The "inferiority" of the weakened population is expressed mainly in the absence of or inability to realize political, social, legal and economic rights (Shoham, 2011).

Our assumption that cases of fatal construction accidents, where most of the victims are foreign workers, will lead to under-enforcement and lenient punishment, if any, is only partially corroborated in this study. There was no significant correlation between the identity of the victim and the decision of whether or not to file an indictment. Furthermore, in those few cases where indictments were filed in fatal construction accidents, the punishments imposed were not less severe for foreign worker victims. However, the many cases of fatal construction accidents where the decision was made not to file indictments may reflect the assumptions of the Marxist school in victimology (Arifi, 2016; Matthews, 2014), which contends that victimhood is characterized by an inability to resist because the victims lack physical strength (small children, women, and the elderly), and social, cultural, economic or political power (immigrants and minorities). Foreign workers cannot express their opposition due to language difficulties and economic dependence on the contractor, who urges them to finish building quickly.

However, for the very few cases where an indictment was filed in a fatal construction accident, in contradiction to the hypothesis, the punishment was found to be stricter than for fatal road accidents. Due to the similarity between fatal construction accidents and fatal road accidents in terms of the offense, the outcome, and exercise of the legal process, we would expect a similar punishment, but the findings showed the opposite. This finding can be explained both by the assumption that when a decision is made to file an indictment in a fatal work accident, it is probably based on solid evidence that can prove a high degree of negligence and as a result, there is a stricter punishment, and by the Marxist structural approach, whereby legislation and punishment do not always serve the direct interests of the wealthy (Hagan, Silva, \& Simpson, 1977).

According to the Marxist structural approach (Larnau, 2016), solving social problems, including problems of delinquency and crime, depends on a significant change in the power structures underlying society. In this case, we are facing the need for a significant structural and systemic change. The contractors, who have economic and social power, are required to look after the welfare of the weakened workers and provide them with all the safety measures at the construction site, and to ensure their safety and training by appointing a safety officer on the site to ensure that all workers are protected. However, in reality, in Foucault's terms (Foucault, 2015; Mills, 2003), contractors do not always provide all safety devices and necessary working conditions, neither do the supervision and enforcement agencies always provide the necessary response. Construction workers, as victims, also indirectly contribute to their victimhood by being afraid to complain for fear of losing their source of income. Their inferiority also stems from language difficulties, integration difficulties, and cultural differences that lead to their inability to cope with those possessing authority and power.

Road accidents, whether fatal or non-fatal, are considered a social problem that affects and endangers the entire Israeli public, and therefore extensive resources are invested in various fields, including legislative amendments, infrastructure, budgets, enforcement and public awareness. However, the problem of fatal construction accidents is not perceived as a social problem, since it impacts only a small, marginal and weakened sector (on structuring an issue as a social problem, see Cavaglion \& Shoham, (2016). Only acknowledging fatal construction accidents as a social problem, while making a systemic change in power structures, might lead to a reduction in the number of fatal work accidents in this industry.

Collecting data for this study was fraught with difficulties because the State Attorney's Office was unable to produce accurate data, since the computer system does not distinguish between deaths in a construction accident caused by negligence and in other circumstances. The focus on one district in which data could be extracted manually and the limited number of cases on which this research is based on make it difficult to draw conclusions about the validity of the theoretical assumptions that find a correlation between the sociodemographic characteristics of construction workers and the nature of decisions taken by law enforcement in fatal construction accidents. At this stage, this study cannot conclude whether the civil identity of many workers in the construction industry is to their disadvantage, as posited in the assumptions of the Marxist 
school of victimology. It is possible, as the structural Marxist school (Larnau, 2016) suggests, that the answer is more complex and related to the characteristics of fatal work accidents in the construction industry and to the different interests of those involved in this field. It is possible that the structural inferiority of construction workers, regardless of ethnicity or nationality, better explains the findings of this study. To answer this question, additional studies are required, based on additional districts or national samples with a larger number of cases than those available to the researchers in this pioneering study.

Construction accidents in general and particularly fatal construction accidents are not inevitable; they can be significantly reduced by appropriate legislative changes, by the authorities investing funds and employing skilled experts, and by raising the awareness of contractors and the general public about safety on construction sites. For this issue to remain on the public agenda and to better understand the victimhood of construction accidents in its full scope, we recommend carrying out similar studies in other districts, not only concerning fatal construction accidents. Furthermore, the effectiveness should be evaluated of recently enacted regulations and directives in reducing the rate of work accidents in general and fatalities in particular, especially in the construction industry.

\section{References}

1. Cohen, R., Ra'anan, N. and Gittelson, N. (2016). Report on Work Accidents in Israel: Status for 2011-2015. Retrieved from the Ministry of Labor, Welfare and Social Services:

https://employment.molsa.gov.il/Employment/SafetyAndHealth/ResearchAndProjects/Reports/Reports/Ac cidentReport2011-2015.pdf(In Hebrew).

2. Danieli, A. (2018, May 30). Since the beginning of the year: a $30 \%$ jump in the number of fatalities of construction workers. Calcalist. Retrieved from: https://www.calcalist.co.il/real estate/articles/0,7340,L3739196,00.html (In Hebrew).

3. Elbashan, Y. (2005). Strangers in the Realm of the Law: Access to Justice in Israel. Bnei-Brak: Hakibutz Hameuchad (In Hebrew).

4. Elias, R. (1986). The politics of victimization, victims, victimology and human rights. Oxford: Oxford University Press.

5. Falandysz, L. (1982). Victimology in radical perspective. In H.J. Schneider (Ed.) The victim in international perspective (pp. 105-114). Berlin: de Gruyter.

6. Feldman, Y. (2008). Who the hell is this victim? The rise and fall of Abraham, the fetter in the 1950s. Mickan, 9, 125- 157. (In Hebrew).

7. Foucault, M. (2015). The Punitive Society: Lectures at the Collège de France, 1972-1973. Davidson, A. I. (Ed.). London: Palgrave Macmillan UK.

8. Gittelson, N., Cohen, R., \& Ra'anan, N. (2015). Report on Work Accidents in Israel: Status Report 2010 - 2014. Ministry of Labor, Welfare and Social Services. Retrieved from https://employment.molsa.gov.il/Employment/SafetyAndHealth/ResearchAndProjects/Reports/Reports/Ac cidentReport2010-2014.pdf (In Hebrew).

9. Gittelson, N., Cohen, R., \& Ra'anan, N. (2016, June). Work accidents in Israel: 2011 - 2015. Periodical surveys 278. National Insurance Institute. Retrieved from:

https://www.btl.gov.il/Publications/survey/Documents/seker 278.pdf (In Hebrew).

10. Hacker, D. (2008). An invitation to the sociology of law and an initial mapping of the scope in Israel. Din Udvarim - Haifa Law Review, 4, 95-129. (In Hebrew).

11. Hagan, J., Silva E. T., \& Simpson, J. H. (1977). Conflict and consensus in the designation of deviance. Social Forces, 56(2), 320-340. 
12. Haney, C. (1991). The Fourteenth Amendment and symbolic legality. Let them eat due process. Law \& Human Behavior, 15(2), 183-216.

13. Israel Police (2014, February 1). Grounds and considerations for closing criminal cases. Procedure of Investigations Division no. 300.01.152 Retrieved from the Israeli Police website: https://www.police.gov.il/menifa/05.300.01.152 1.pdf (In Hebrew).

14. Kirchhoff, G. F. (1990). Victimology, human rights and criminal procedure. Paper presented in the workshop: Human rights of the victim and criminal justice. International society of criminology, Miskolc, Hungary.

15. Kirshenbaum, A. (2009). Victimology and Jewish Law: Focusing on the Victim and the Offended. Law and Business, 10, 147-182. Retrieved from: http://portal.idc.ac.il/he/lawreview/volumes/volume10/documents/kirshnbaum.pdf (In Hebrew).

16. Knesset, Labor, Welfare and Health Committee (2018, February 5). Protocol No. 700. Retrieved from the Knesset website:

https://docs.google.com/viewer?url=http\%3A\%2F\%2Ffs.knesset.gov.il\%2F\%2F20\%2FCommittees\%2F20 pt v_488863.doc (In Hebrew).

17. Landau, S. (2003). The Social Perception of Victims: Outlines for the Definition of the Dimensions of Victimology. In M. Hovav, L.Sebba, \& M. Amir, (Eds.) Trends in Criminology: Theory, Policy and Practice (pp: 797-809). Jerusalem: The Harry and Michael Sacher Institute for Legislative Research and Comparative Law, the Hebrew University of Jerusalem (In Hebrew).

18. Larnau, H. (2016). Crime and Law Enforcement - Theory, Policy, Criticism. Haifa: Pardes Publishing. (In Hebrew).

19. Marx, K. and Engels, P. (1975). The Communist Manifesto. Chicago: Kerr, 1982.

20. Matthews, R. A. (2014). Marxist criminology. In M. Schwartz \& S. Hatty (Eds.), Controversies in critical criminology. (pp. 1-14). Cincinnati: Oh:Tylor \& Francis.

21. Mendelsohn, B. (1963). The Origin of the Doctrine of Victimology. Experta Criminologica ,3, 239-44.

22. Mills, S. (2003). Michel Foucault. London and New York: Routledge.

23. Nathan, G. (2011, December 13). Non-Israelis in Israel (Foreigners, Foreign Workers, Refugees, Infiltrators and Asylum Seekers), 2010-2011. Retrieved from the Knesset website:

http://www.knesset.gov.il/mmm/data/pdf/m02986.pdf (In Hebrew).

24. Public Committee for the Advancement of Occupational Safety and Health in the State of Israel (Adam Committee) (2014, March). Report and recommendations. Retrieved from: http://graphics-

lapam.org.il/clients/calcala/vadat adam 2/vaadat adam.html (In Hebrew).

25. Ra'anan, N. (2018). Report on work accident in Israel - the first median for 2017. Retrieved from the Ministry of Labor, Welfare and Social Services website:

https://employment.molsa.gov.il/Employment/SafetyAndHealth/ResearchAndProjects/Reports/Reports/Ac cidentReport S1-2017.pdf. (In Hebrew).

26. Ra'anan, N., Cohen, R., Gittelson, N., \& Berna, A. (2017). Report on Work Accidents and Occupational Illness: Status Report 2012 - 2016. Retrieved from the Ministry of Labor, Welfare and Social Services website:

https://employment.molsa.gov.il/Employment/SafetyAndHealth/ResearchAndProjects/Reports/Reports/Ac cidentReport2012-2016.pdf(In Hebrew).

27. Rattner, A., \& Fishman, G. (2004). Justice for all? Jews and Arabs in the Israeli legal system. In: E. Levy, A. Shadmi, \& Y. Kim (Eds.). Seeking Justice - Studies in Crime and Law Enforcement in Israel (pp. 110-185). Tel Aviv: Cherikover Beit Berl. (In Hebrew). 
28. Shoham, E. (2009). Undocumented foreign workers detained in the Israeli prison system. In M. Shechory, S. Ben David, \& D. Soen (Eds). Work immigrants and social problems: An international perspective (pp.189205). New York: Nova Science Publishers.

29. Shoham, E. (2011). The back yard of the detention system in Israel: foreign workers without a permit. Israeli criminology, 1, 29-53. (In Hebrew).

30. Shoham, E.. \& Abulafia, J. (2010). Judicial decisions on violent offenses between spouses in the Magistrate's Court. Megamot, 47, 103-129. (In Hebrew).

31. Shoham, E. Doron, S. (eds.) (2016). Between visibility and transparency - the attitude toward "the other" in Israeli society. Ashkelon: Ashkelon Academic College. (In Hebrew).

32. Shoham, G. S., \& Hoffman, J. (1991). A primer in the sociology of crime. N.Y.: Harrow and Heston, publisher.

33. Simpson, S. S. (1989). Feminist theory, crime and justice. Criminology, 27, 605-631.

34. Taylor, I., Walton, P., \& Young, J. (1975) Critical Criminology. London: Routledge and Kegan Paul.

35. The State Comptroller (2016). Ministry of Economy and Industry - Workers' safety and health. Annual Report 66c. Retrieved from the State Comptroller's website:

http://www.mevaker.gov.il/he/Reports/Report 537/1986e269-7871-4a40-a1a5-e639fca550f6/222safety.pdf (In Hebrew).

36. The state prosecutor (2018, January 14). Directive 1.3 - Closing of cases on grounds of "lack of evidence" and grounds for "lack of guilt". Retrieved from the Ministry of Justice website:

http://www.justice.gov.il/Units/StateAttorney/Guidelines/001.3.pdf (In Hebrew).

37. Yaron, L. (2017, November 23). Ardan and Katz refuse to budget a unit for the investigation of constuction accidents, and its establishment is postponed to 2019. Haaretz. Retrieved from:

https://www.haaretz.co.il/news/education/.premium-1.4624686? =\&ts=1515357900148 (In Hebrew).

38. Zeira, G. (2015, December 14). Work accidents in the construction industry. Retrieved from the Knesset, Research and Information: https://fs.knesset.gov.il/globaldocs/MMM/59e62efd-6493-e511-80d600155d0204d4/2 59e62efd-6493-e511-80d6-00155d0204d4 11 7970.pdf(In Hebrew).

39. Zeira, G. (2016, February 8). Data on fatalities in work accidents in the construction industry in 2010-2015. Retrieved from the Knesset, Research and Information: Center:

https://fs.knesset.gov.il/globaldocs/MMM/b111c97c-79ce-e511-80d0-00155d0acb9e/2 b111c97c-79cee511-80d0-00155d0acb9e 11 9205.pdf (In Hebrew).

40. Zeira, G. (2016, September 26). Data on investigation procedures and legal proceedings following work accidents in the construction industry: update document. Retrieved from the Knesset, Research and Information Center: https://fs.knesset.gov.il/globaldocs/MMM/904b780b-cfde-e511-80d600155d0204d4/2 904b780b-cfde-e511-80d6-00155d0204d4_11_10434.pdf (In Hebrew).

41. Zeira, G. (2017, December 27). Data on the files of the State Attorney's Office that were filed between 2010 and February 2016 on suspicion of negligent offenses in cases of work accidents in the construction industry. Retrieved from the Knesset, Research and Information Center: https://fs.knesset.gov.il/globaldocs/MMM/55c5c241-8fe8-e711-80de-00155d0a0235/2 55c5c241-8fe8e711-80de-00155d0a0235 11 7923.pdf (In Hebrew).

42. Zisser, B. (1999). About left and right: a window for modern ideological discourse. Tel Aviv: Schocken Books. (In Hebrew). 